\title{
Lineage Matters: DNA, Race, and Gene Talk in Judaism and Messianic Judaism
}

\author{
Sarah Imhoff and Hillary Kaell
}

In July 2012, Jewish Voice host Jonathan Bernis began his weekly television program by telling the audience: "One of the questions I'm asked by Christians who love Jewish people and Israel is 'How can I find out if I am Jewish? I just feel so Jewish. Is there any way to know?'" Then he introduced his guest: "My guest today says yes you can. He claims your history is actually written into your cells. He is a DNA expert who helps people discover their ancestry through DNA testing, and he is the world's foremost authority on DNA testing as it relates to Jewish lineage. Please help me welcome to Jewish Voice DNA expert Bennett Greenspan." ${ }^{1}$

At first, Bernis and Greenspan may seem like odd bedfellows. Bernis is a Messianic Jew and his target audience is evangelical and Pentecostal Christians with connections to Messianic Judaism, a loose movement of congregations, missionary associations, and online ministries that incorporate aspects of Jewish culture and ritual into Christianity. Messianic Jews believe that Judaism is a heritable "genetic" lineage and that Jews, therefore, remain Jewish even after they are "completed" through belief in the messiahship of Jesus. Although this idea is the fundamental basis for the movement, today upwards of 70 percent of congregants are actually what insiders call Gentile Believers (GBs), a fact that few scholars have addressed in depth likely because "ethnic" Jews like Bernis comprise Messianic Judaism's public face. ${ }^{2}$

By contrast, Greenspan, CEO of the largest personal DNA testing company in the world, is Jewish, not Messianic. And the majority of North American Jews have a "visceral distaste" for Messianics, whom they understand to appropriate Jewish culture and target Jews for Christian evangelization. What Greenspan's interview suggests, however, is that DNA is one place where Judaism and Messianic Judaism converge, at least on the surface. Greenspan's business rests on assumptions that both groups share about the relationship between

Religion and American Culture: A Journal of Interpretation, Vol. 27, Issue 1, pp. 95-127, ISSN: 1052-1151, electronic ISSN: 1533-8568. () 2017 by The Center for the Study of Religion and American Culture. All rights reserved. Please direct all requests for permission to photocopy or reproduce article content through the University of California Press's Reprints and Permissions web page, http://www.ucpress.edu/journals.php?p=reprints. DOI: https://doi.org/10.1525/rac.2017.27.1.95. 
DNA and Jewish identity: the claim that DNA can help people understand something fundamental about themselves and their relationship to others.

Broadly, DNA is often used as a metaphor for core aspects of identity. For instance, the Jewish Daily Forward claimed that a Jewish understanding of suffering is "engrained in our DNA." At an annual Reform conference, Rabbi Rick Jacobs noted how synagogue greeters had "smiles on their faces and hospitality in their DNA." 4 Yet the marketing of personal DNA testing and the conversation it spurs go beyond the metaphorical. As Elizabeth Hirschman and Donald Panther-Yates argue, DNA results help group members tell socially meaningful stories about their individual and corporate identities. ${ }^{5}$ Both Jews and Messianic Jews often discuss the implications of DNA in this regard. Jews, however, are far more likely to have their own DNA tested than gentile Messianics, who instead hint at origins, make intentional omissions, and engage in snippets of conversation: "He's Jewish, right?" "No, he's not... I mean, as far as he knows right now, but he's thinking of doing his DNA, you know."

Based on ethnographic and archival research conducted on North American Judaism and Messianic Judaism, ${ }^{6}$ this article argues that each group uses DNA in what appears to be sociologically similar ways, but they actually differ profoundly at the theological level. Through this comparative approach, we demonstrate clearly what scholars have only begun to recognize: how theological commitments may drive investments in and interpretations of genetic science. Further, we show how religiously significant identities associated with race, ethnicity, or lineage interact with DNA science, coming to be viewed as inalienable qualities that reside in the self but move beyond phenotype alone.

While Jews and Messianic Jews sometimes use DNA testing to make sense of their identity, we have found "gene talk" to be even more pervasive and central. We draw this phrase from Kim Tallbear's work on Native Americans and DNA. She uses it to refer to "the idea that essential truths about identity inhere in sequences of DNA," which bolsters legal and political claims along with quests for identity. ${ }^{7}$ In all of these processes, Tallbear notes, gene talk often takes interpretation for fact and even misleads. In our respective research on Jews and Messianic Jews, we have found similar kinds of gene talk, though the political stakes clearly differ from Native American cases. We also build on related research about Jews, including Susan Martha Kahn's studies of the interactions between genetics, medicine, and halakhah, and Nadia Abu El-Hajj's work on the politics of genetic anthropology. ${ }^{8}$ Our research complements this work in two ways. 
First, we examine how people talk about genetics in their everyday lives. Among both Jews and Messianic Jews, "Jewishness" is freighted with competing claims. In Judaism, halakhic rules (having a Jewish mother or converting) compete with Reform and Reconstructionist rules (having one Jewish parent or converting). Even halakhah generates conflicting opinions, as the growing literature on assisted reproductive technologies shows. ${ }^{9}$ In Messianic Judaism, which understands Jewishness as inalienable, until recently denominational authorities rejected even those gentile conversions recognized by mainstream Jews, since a gentile could never alter his essential makeup to become a Jew. ${ }^{10}$ Although Jewish and Messianic conceptions differ, in both cases DNA is attractive because it seems to offer empirical categorizations of Jewish identity that are deeply complex and contested. In other words, like Tallbear, we focus less on the science of DNA than on how people make social meaning out of technological possibilities.

Because of our focus on emic interpretations, we employ terms and categories that circulate in the communities we study, whether or not these reflect current scientific or scholarly views. For example, mainstream Jews may refer to "proofs" of Jewishness and Messianic Jews may talk (often interchangeably) about "ethnic" Jews, "bloodlines," or "lineages." We also use etic categories to further our analysis. For example, although when Jews and Messianic Jews engage in gene talk they rarely use the word "race," our contention is that they often rely on the concept. ${ }^{11}$ To be clear, their interpretations are not racist in any simplistic sense but rather racialist in that they posit "heritable characteristics" and "certain traits and tendencies" in one group that are "not share[d] with members of any other race," as theorist Kwame Anthony Appiah explains in his definition of the term. ${ }^{12}$

These colloquial uses of gene talk also point to the second way our research builds on existing scholarship: it illuminates gene talk's theological context, which has gone largely unexamined by social and cultural historians. Gene talk dovetails with, and builds upon, the American embrace of ethnic heritage. In Roots Too, historian Matthew Frye Jacobson shows how U.S.-born Americans embraced Irish, Italian, Polish, and other European ethnic pasts. This "ethnic revival," a legacy of the 1960s, birthed a new way of talking about identity-a "new syntax of nationality and belonging."13 The idea of a white ethnic revival has played a central role in scholarship on both Jews and Messianic Jews. ${ }^{14}$ Embracing ethnic pride allowed Jews to be both American and distinctive, an essential part of the "salad bowl" of North American identities. The same movement inspired the development of contemporary Messianic Judaism, whose early leaders were 
ethnic Jews attending Protestant churches in the late 1960s and 1970s. Further, the (few) previous studies of Messianic Judaism that describe what we call gene talk posit that it arises in part from how GBs, assumed to be "white ethnics," are afflicted by a postmodern sense of rootlessness. They are drawn to the movement because Jewishness gives them an identity. ${ }^{15}$

When scholars have analyzed this ethnic revival (and to some extent, gene talk) within religious communities, especially among Jews and Catholics, they have tended to overlook religion itself, or relegate it to another marker of cultural difference. ${ }^{16}$ As such, they position gene talk as a discourse about ethnic location without clarifying how it can also be about location in a theological or cosmic narrative. What we analyze here sometimes looks like "ethnic revival." We might have said that gene talk and DNA testing form a new wave-or a new tool in the toolkit-of ethnic revival. Yet while this is true, it is not the whole story. Gene talk constructs much more than just an ethnos: it constructs religious identities and makes theological claims. When Messianic GBs talk about DNA and blood, for example, they unite biblical exegesis, intuitive feeling, and what they view to be scientific proofs. Even in the case of unaffiliated Jews, a secularized theological narrative underwrites gene talk and its significance.

Our work, therefore, builds on a growing number of studies about the intersection of religion, race, and science. Gil Anidjar has recently argued that blood continually factors into biblical descriptions of sacrificial and covenantal rituals, but the materiality of kinship is not blood-based, relying instead on naming, memory, and genealogical lists; it was only after the Middle Ages that blood was biologized as the basis for family descent. ${ }^{17}$ Focusing on the nineteenth century, Colin Kidd has shown how modern "race science" threatened the intellectual authority of scripture and thereby compelled its reinterpretation, while anthropologists Audrey and Brian Smedley note that theologically based presumptions continue to survive in ideas about race, including those deemed scientific. ${ }^{18}$ Other studies, such as Circe Sturm's work on white "racial shifters" who come to see themselves as Cherokee, clarify how DNA evidence intersects with spiritual seeking; individuals who believe they have discovered Cherokee "blood" may feel that indigenous cosmologies are more fulfilling than their Christian or secular upbringings. ${ }^{19}$

Our aim is to bring together these disparate strands of research by explicitly foregrounding how race/ethnicity, genetics, and theology intersect in both the institutional and "open" places of everyday religious practice. Thus far, this complex relationship is only hinted at in each of the literatures above. We begin by analyzing what 
we mean by "gene talk," where it happens, and what it sounds like. We then explore how constructions of race and lineage are imbued with distinctive religious significance. We conclude by clarifying gene talk's authorizing work in its respective Jewish and Messianic Jewish contexts.

\section{The Contours of Gene Talk among Jews and Messianic Jews}

Gene talk happens in synagogues, over meals, in front of televisions, and online. Here we examine two major spaces where it occurs: those we call "institutional," such as activities in congregations, genealogy conferences, and community seminars; and those we call "open," largely online, such as blogs, YouTube, webinars, and websites.

Gene talk in institutional spaces takes a number of forms. Jewish and Messianic congregations sponsor guest speakers or official discussions, such as a New Jersey synagogue's April 2014 "DNA and Jewish Genealogy" discussion led by a chemist and amateur genealogist. ${ }^{20}$ There are often other kinds of contacts, too: for instance, the Jewish Genealogical Society of Los Angeles, which has ongoing interest in DNA studies, often meets in synagogues. Gene talk also happens in institutional settings that are not explicitly religious, such as Jewish community and learning centers. Genealogy conferences, meetings, and seminars with a focus on Jewishness and DNA - and there are hundreds, from the local level to the international-are growing each year.

The most populous space for gene talk, however, is an "open" one: the Internet. From professional productions like Bernis's Jewish Voice or Bennett's Family Tree DNA's webinars to amateur message boards, these spaces allow anyone to participate, knowledgeable genealogists and comparatively uninformed newcomers alike. Not surprisingly, open spaces generally include a more diverse group than institutional spaces. Because these spaces allow for anonymity, Messianics can also connect to Jewish websites and with (potentially) Jewish participants in ways they usually do not offline.

Institutional spaces and open spaces inform one another. Participants use similar language, discussing haplogroups and cousins, migrations, and religious practices. Experts who offer webinars also offer in-person seminars. The most active users of message boards attend lectures and conferences, and the speakers there often refer their audience to websites. Some spaces bridge the two: websites such as chabad.org and aish.com offer institutionally approved content written by religious experts (often rabbis) and comment sections where anyone can post. 
Jewish Gene Talk

All this gene talk about Jews suggests that DNA tells us something about Jewishness. This is notable right from the start: North American Christians or Muslims do not engage in this kind of gene talk about identity. Some white ethnic groups participate in gene talk, but they do so less often and with seemingly less intensity. Many DNA testing companies offer services specifically targeting Jews: 23andme, Family Tree DNA, DNA Consultants, and Roots for Real all advertise tests that offer insight into Jewish lineage and identity. "Jews: Are You Jewish?" one DNA testing website asked. ${ }^{21}$ In open spaces, discussion groups continue to rise. As of January 2015, "Tracing the TribeJewish Genealogy on Facebook" had more than 6,700 members. The "Jewish Genealogy Portal" group had 4,500 members. JewishGen, one of the largest Jewish genealogy websites, is affiliated with the Museum of Jewish Heritage and Ancestry.com, includes information on more than five million individuals submitted by more than 4,500 Jewish genealogists. ${ }^{22}$ Ancestry.com's discussion groups related to Jewish DNA have more than 6,000 posts. When Jews engage in gene talk, it speaks to the perennial question of who is a Jew: are Jews defined by religious law, ethnicity, affiliation, descent, or some combination of these?

Although Jews have long talked about Jewish identity and peoplehood, the 1997 discovery of the Cohen Modal Haplotype $(\mathrm{CMH})$ inaugurated a new type of response. The $\mathrm{CMH}$, sometimes called the "Cohen gene," is not technically a gene. It is a sequence of noncoding DNA found on the $\mathrm{Y}$ chromosomes of some Jewish men who identify as cohanim, the Hebrew word for members of the priestly class. Although the $\mathrm{CMH}$ appears in a significant proportion of the Jewish men who identify as cohanim (around 50 percent in the first study and about 30 percent in a subsequent study of an extended sequence) and in relatively few non-Jews, its presence cannot prove Jewishness. ${ }^{23}$

Nevertheless, these $\mathrm{CMH}$ studies, or tertiary understandings of them, are popular topics of conversation. One reason, the least frequently discussed, is a scientifically legitimate one. The presence of $\mathrm{CMH}$ in both Sephardim and Ashkenazim provides genetic evidence for the common origin of the two Jewish groups. Thus, despite centuries of these two populations living in geographically distant regions, the narratives of a shared past are supported by the data. Another reason for the popularity of CHM studies is not a scientifically verifiable one. Many Jews see genetic evidence as proof of the biblical stories of the high priest Aaron. Because religiously determined status as a Cohen depends on patrilineal lines, and because $Y$ chromosomes are 
passed directly-barring any mutations-from father to son, according to the theoretical ideal of one original priest who engendered all subsequent cohanim, each of them should have the same pattern of alleles on their Y chromosomes. For instance, one Ancestry.com member wrote: "The identification with Kohanim and Levihim has been a[n] oral tradition that has continued through the ages... One must remember that both [sides] share common DNA identities if the tale of the brothers, Moses and Aaron are historically correct." ${ }^{24}$ Thus evidence of a genetic connection between Ashkenazi and Separdi populations is deployed to prove the truth of biblical narratives. Other commentators are even more explicit and enthusiastic. Yaakov Kleiman, Orthodox rabbi and lecturer at Aish HaTorah, celebrates "the fascinating story of how DNA studies confirm an ancient biblical tradition." ${ }^{25}$

A third reason for the popularity of gene talk about $\mathrm{CMH}$ is that people often want to know if they, or relatives, are members of a priestly class. The Chabad website asks if we can prove claims about cohanim, and answers, "Today [we] can, and the key is DNA testing." ${ }^{26}$ In 2004, the Los Angeles Times reported that Greenspan asked a man who had tested with his company, "Did you know you were Jewish?" after he found out the man's DNA included the CMH. ${ }^{27}$ This discourse of "proving" Jewishness or cohen identity is reflected from institutional spaces into open ones, where it proliferates. After explaining that her husband's family had stories of being cohanim, one woman asked, "Can I get my son tested to find out if that's true?" Even after hearing that testing for the "Cohen gene" would not, in fact, say if a man is a Cohen, an American Sephardi man responded that he still wanted to have his DNA tested because "I want to know for sure." Science seems also to authorize certain people as Jews. Discussions about nonwhite groups claiming Jewishness, such as the Lemba of South Africa, the Bene Israel of India, and Hispanic communities that identify as anusim (the descendants of forcibly converted Jews) have often focused on DNA. ${ }^{28}$ Following the discovery of the $\mathrm{CMH}$ among their members, the Lemba, for instance, have been embraced as connected to the Jewish community.

DNA services now market the ability to classify men and women genetically beyond CMH. Haplogroups such as J1 and R1a appear more often in Jewish populations than in other populations with Eastern European lineage. Maternal DNA offers yet another possibility: tracing genetic lines through mothers, mothers' mothers, and so on. Though both biologically and halakhically Jewishness cannot be genetically determined, such conversations move beyond scientific specificities to focus on what matters most to the people 
involved: cultivating a sense of the Jewish self and, in particular, the Jewish self as part of a Jewish people. JewishGen, for example, claims to offer services at "the cutting edge of scientific technology," but its advertisements promise something rather different, too: "For some families, especially when there are no records and the paper trail dead ends, this tool may be your only means of establishing a relationship with potential family. With a simple swab of your inner cheek and scientific analysis of just a small portion of your DNA, relationships can be determined over a period in excess of a few thousand years." ${ }^{29}$ Even without explicitly religious language, JewishGen conveys the importance of peoplehood and Jewish connections, and it claims that DNA is one way-sometimes "the only means" - of forging those connections.

Gene talk reflects but also cultivates these links. One "Tracing the Tribe" poster seeking information about his Jewish ancestors wrote: "I recently did a DNA test on 23andme and ... I'm trying to locate where my 3rd Great Grandmother originated from ... My Grand Aunt says she came from Germany, but my DNA admixture says otherwise." Dozens of responders chimed in with their own advice and experiences: one explained that she has a similar genetic "admixture," and another said, "I have [the same surname] that shows up from my $\mathrm{ftDna}$... I think we must have a connection." ${ }^{\prime 30}$ On MyJewishLearning. com, a self-identified secular Jew described how excited he was to learn that "DNA testing [has] been able to show how many genes we have are Jewish," evidence he equated with "direct blood." ${ }^{31}$ Gene talk connects participants to others-they took the same DNA tests; they sometimes share haplogroups; they may share surnames or ancestral towns; they may even make personal connections and join family trees. Gene talk reinforces the idea of a Jewish people both by building a community of genealogists helping one another and by offering apparent scientific support for the "objective" reality of Jewish lineage.

At times, the conflation of science and peoplehood has clear political stakes. For example, in 2014 the World Jewish Congress published an article entitled "75 Percent of Today's Jews Have Middle Eastern Origins, Says DNA Pioneer." ${ }^{32}$ The pioneer was Bennett Greenspan, who sought to counter Israeli academic Shlomo Sand's contention that Israeli Jews are actually descendants of Khazars, thus negating their theologically based claim to the present-day land of Israel. In response, Greenspan told Haaretz: "We're not interlopers who came here from Eastern Europe, and we're not Serbs or Kazars. You can use whatever polemic you want to discredit the Jews or discredit the nation, but saying that we weren't here is a lie.." ${ }^{\prime 3}$ Occasional comments in the open space of internet message boards also claim that 
Jewish DNA is a Zionist conspiracy, underlining a different kind of ideological and political use for DNA.

In institutional contexts, leaders are less likely to make explicit claims about adjudicating Jewishness according to DNA. However, they too use gene talk to support theological or historical narratives of Jewish peoplehood. In 2014, Chicago Jewish leadership chose David Laskin's The Family for its annual "one book, one community" program. Laskin uses gene talk to connect Jewish readers back to biblical figures. He begins with a little known nineteenth-century scribe: "Shimon Dov was a member of the Jewish priestly caste that traces its ancestry (through the male line) back to Moses' brother Aaron, the first high priest of the Israelites. The biblical Ezra also stood in this line-'Ezra the priest, the scribe of the Law of the God of Heaven.' Ezra HaKohen, HaSofer-Ezra the priest, the scribe-was therefore Shimon Dov's spiritual father and very possibly his blood ancestor as well, since science and scripture eerily concur that the Kohain DNA has remained intact all the way back to Aaron. ${ }^{\prime 34}$ Chicago area synagogues and Jewish institutions hosted "Introduction to Jewish Genealogy" programs along with meet-the-author and book group gatherings. The experts at these gatherings clarified that DNA cannot determine Jewishness, while also using gene talk to bolster a sense of religious continuity and the idea that Jews are "a family."

Jews from all religious affiliations (and non-affiliation) participate in gene talk. Chabad.org and Aish.com, the two largest websites for traditionally observant Jews, both discuss DNA. Chabad connects DNA evidence to religious practice, using the former as an argument for pursuing the latter. "Ashkenazi, Sephardi, Yemenite and Italian kohanim can actually trace their backgrounds back to the Jews of the Exodus. And if modern science has given us the tools to prove common ancestry, isn't the next obvious step to dedicate ourselves to our common purpose-G-d's Torah and mitzvot?"35 This stance is no surprise, given Chabad's mission to bring non-Orthodox Jews to greater religious observance. But the rhetoric moves beyond the value of observance; it also claims the importance of "common ancestry," by making biblical reference to the "Jews of Exodus." Moreover, Chabad claims that this genetic information points to the particular morality and religious uprightness of the Jewish people: "But almost $100 \%$ of all men with family tradition of priesthood do descend from kohanim. Generation after generation of Jewish women were faithful to their husbands and their tradition. What a proud record of fidelity... This devotion to our spouses and our G-d has always been the way of the Jew. ${ }^{\prime \prime 36} \mathrm{~A}$ history of endogamy, the quality that made Ashkenazi Jews first of interest to genetic researchers, here functions as a sign of religious morality. 
MyJewishLearning.com, a denominationally unaffiliated website, contains more scientific information and less traditional exegesis than on Chabad.org, but the gene talk there nevertheless fosters a sense of connection, both to other Jews and to a history of Judaism. ${ }^{37}$ The comment sections for many articles_- "Ashkenazim, Sephardim, Mizrahim," "Native Americans and Jews," and others-overflow with comments from both non-Jews ( "[M]y daughter and I have a love for Israel and want to live there one day. Deep down we feel we are Jewish") and Jews ("I am from the Tribe of Levi... We Jews go back a few thousand years.") ${ }^{38}$ A Forbes.com article about "Jewish DNA" generated comments about the color of Moses' skin, the Kingdom of Judah and "Judean DNA," and the biblical stories of Abraham, Isaac, and Jacob. ${ }^{39}$ Compared to the Chabad website, far fewer participants frame their remarks in terms of Torah observance, but the relationship of genetic information to biblical history is still a major source of conversation.

\section{Messianic Gene Talk}

Previous studies of Messianic Judaism posit that gene talk is a response to the social hierarchy between Jews and gentiles in most congregations. ${ }^{40}$ This functionalist interpretation assumes that GBs seek Jewish blood in order to gain authority within the movement. While this may be true for some long-term members, it fails to account for the vast majority of GBs who "gene talk" without ever undergoing DNA testing or insisting on being accepted as Jews, at least in institutional terms. As noted above, a second hypothesis in previous studies ties GBs to the broader "white ethnic" revival. This line of reasoning contends that, amid a growing sense of postmodern rootlessness, some white Americans (GBs) find that being Jewish gives them a clear sense of identity. ${ }^{41}$ Without entirely dismissing this trend, it fails to explain why GBs who self-identify as racial minorities, such as African Americans or Latinos, also speculate about their lineage. Why does it appeal?

To answer this question one must take its religious dimension seriously. Most Messianics, whether they identify as ethnically Jewish or gentile, come to the movement from Pentecostal or charismatic churches that adhere to a form of premillennialist theology. ${ }^{42}$ As such, they believe that the Christian gospel is universal but that only contemporary Jews are the genetic descendants of biblical Israelites. Anthropologist Fenella Cannell succinctly sums up a similar theological outlook in her work on U.S. Latter-day Saints who, she writes, reiterate "the 'closed' blood of Israelite lineage, while simultaneously extending the offer of Church membership through universal mission. ${ }^{\prime 3}$ Yet 
there are significant differences between what Cannell describes and Messianic Judaism. LDS are mainly concerned with how their own family histories intersect with personal lineage ascriptions that situate each believer as a member (or not) of an Israelite tribe, which they believe has bearing upon their role in the End Times and stipulates the other people with whom they will be "in gathered." In contrast, for Messianics contemporary "ethnic" Jews will play a unique role in the coming apocalypse and, just as important, are also understood to be genetically related to Jesus. The latter idea is especially crucial for the heirs of pietistic Christianity - such as North American charismatics and many evangelicals-who prize an intimate relationship with Jesus. To feel this closeness, and to act on the question "What would Jesus do?" takes on radically new meaning if one thinks of him as raced, that is as an ethnic Jew living in a particular historical context. GBs strongly embrace this view. For them, it means that having Jewish "blood," or at least being in close contact with Jews (as allies and students of their religious culture), is a tangible way to propel the coming End Times and to nurture closeness with the incarnated Son of God, in the form he took on earth.

While Messianics concur that ethnic Jews are situated at the heart of eschatological and biblical history, they interpret this fact in a variety of ways, especially since the majority of congregants are adept seekers who gather religious (and DNA-related) information from many sources. They log into Jewish websites and genealogy blogs and access popular media about science. They listen to televangelists and may attend a church on Sunday and a Messianic congregation on Saturday. As a result, gene talk is constantly circulating and being reauthorized by various "experts," although most of the Jewish Messianic leadership treat it with a fair amount of suspicion. If leaders invite guest speakers to their congregations to discuss the discovery of "hidden" Jewish DNA, for example, it is normally limited to specific groups, like the Spanish/Portuguese anusim, Lemba, or Cochin Jews, that are also recognized by at least some mainstream American Jews. ${ }^{44}$

Congregational leaders' ambivalence about GB gene talk speaks in part to ideas that formed the original basis for Messianic Judaism. As mainstream Jews proudly asserted an ethnic heritage in the late 1960s and 1970s, a core of ethnically Jewish members in Protestant churches also felt a renewed interest in their roots, leading them to reject many churches' policy of discouraging converts from "Judaizing" or even marrying one another. ${ }^{45}$ As a result, and much to the confusion of mainstream Jews, Messianic leaders regularly assert that they are building a bulwark against Jewish assimilation into Christianity. This idea rests on the assertion that Judaism is an inalienable part of one's 
DNA, which ethnically Jewish congregants strenuously defend. Jerry, who attends a southwestern congregation called Beth Yeshua, was raised Jewish. "Of course it's a genetic race," he says. "[If people ask if I'm still Jewish] usually I'll say something ridiculous like: Okay. So what does that make me then? Am I Italian now? Am I Irish? Am I Black? What am I now then? Nothing's changed on me. I've accepted the Messiah." For most Messianics, just as Jews do not change their "genetic race" once they believe in Jesus, gentiles can never become Jews even if they undergo a conversion considered halakhic by orthodox Jewish standards. ${ }^{46}$

Messianic leaders also police the boundaries of ethnic Judaism because they are leery of fringe theologies in evangelical and Pentecostal Christianity that involve "the identification of invisible Israelites" among non-Judaic groups. ${ }^{47}$ British Israelism, the most influential of these theologies, identified white Anglo-Saxons as the "true" Israelites and relegated contemporary Jews to a mixed race with no theological significance. ${ }^{48}$ Messianic Jewish leaders (and most members) utterly reject this theology, along with similar replacement theologies that filter into their congregations by way especially of African immigrants from Adventist or independent churches. ${ }^{49}$ They often provoke a virulent response from leaders. Rabbi Mike, an affable man who heads a southern congregation, was emphatic: "I've actually had to do teachings because they'll try to infiltrate into your congregation. And it's like a cancer! You literally got to cut it out and get rid of it."

Messianic views of Jewishness as a bloodline or lineage are not, however, merely reductionist or essentialist, especially since the definition of an "ethnic Jew" remains contested and variable. At Beit HaMoshiach, a congregation in a large northeastern city, Pastor David estimates that about 25 percent of the members are ethnically Jewish, which he defines as individuals raised by Jewish parents who came to belief in Yeshua (Jesus) as adults-an experience that mirrors his own biography. Pastor David strongly discourages any discovery of roots among what he calls "Jewish wannabees" (a common derogatory term in the movement).$^{50}$ By contrast, Pastor Eric estimates that his southwestern congregation has about 40 percent Jews. For his community, Jews may have any level of heritage on either side, have recently discovered their roots, or be married to someone in either category. Indeed, Pastor Eric, who is not Jewish, is married to the daughter of a celebrated Messianic rabbi. Because Messianic Judaism is patriarchal, Eric heads the congregation even though his wife has the "better" bloodline. Defining Jewishness as acquired through one's spouse cements his own authority, though most congregations prefer a "real" Jew. Perhaps as a result, recently Eric's congregants (and likely he 
himself) have started discussing whether he might actually have hidden Jewish ancestry.

Of course, lived experience often differs from leaders' desires and expectations. Whether or not they try to contain or even suppress it, gene talk remains so prevalent that most GBs encounter it shortly after their arrival: Have you done your DNA? ... What's your mother's maiden name? ... Where's your family from? Because few GBs actually test their DNA, this gene talk remains a space of imagined possibilities. It also tends to follow a particular paradigm. Polly, a sixty-eight-year-old from South Bend, Indiana, offers a good example. The granddaughter of Slovak Catholic immigrants, Polly moved to the southwest with her husband. After their divorce in the mid-1980s, she was born again at a Baptist church and then joined a Pentecostal church, where she first heard about Messianic Judaism. In 2001, she felt called to visit a congregation. After services the first day, she sat down at lunch. She recounts,

Some man was behind me and I could tell he was [Hispanic]. And he tapped me on the shoulder and I turned around and he says nothing like, "Hi! How are you?" Just: "What's your mother's maiden name?" I said, "Beirutz." He says, "Ha! You're a Jew." I said, "No. All four of my grandparents are really strong Roman Catholic." He says, "Well, looking at you, I think you've got Jewish roots." I said, "Okay. Thank you." And I ate my food. I wasn't there for the Jewishness. I was there for the [biblical] truth.

But the idea began to germinate as she kept attending the congregation. Polly researched her grandparents' villages online and traced surnames from her former parish. She asked family members if her mother's father had been Jewish. The response was cryptic: "Well, that would explain a lot." She saw Jewish people who looked just like her cousin, Kenny. She asked him to get a DNA test, but he refused.

These, then, are the most common patterns in gene talk: a relative or a stranger first observes that a GB may have Jewish roots; the major clue comes from a family name; now deceased relatives inexplicably mentioned or did something related to Judaism. ${ }^{51}$ Gene talk often focuses on the maternal line because, although few Messianics adhere strictly to halakhic ideas about descent, there is still an authority that comes with tracing Judaism through the mother. Like Polly, GBs often highlight their relatives' cryptic responses - "Well, that would explain a lot" - as further proof. Among gentile believers, gene talk always hints but never declaims. This talk circulates through congregations, offering tantalizing "what ifs" that demonstrate the thin membrane dividing bloodline Jews from gentiles, as well as the depth 
of individual GBs' feelings of closeness with Jesus (to the degree that they might, in fact, share his blood). Because it is the talk that matters, GBs like Polly rarely actually take DNA tests, even if they say they considered it or asked relatives to do so. Further, rather than ascribing to a simplistic one-to-one correspondence between genotype and phenotype, ${ }^{52}$ GBs engage multiple modes of valuating relatedness that combine elements of Christian theology and U.S. culture to talk about genetic inheritance as sometimes physical, but also as discoverable in personality traits or spiritual attributes. Thus even supposedly inalienable DNA retains an element of mystery and surprise.

\section{Markers of Descent: DNA, Race, and Chosenness}

For Jews, religious ideas are foundational for gene talk, though they seldom emphasize theological content. By contrast, Messianics continually, and explicitly, highlight its biblicism. The difference comes to the fore vividly through the theological lens of chosenness as it dovetails with American ideas about race. For Jews, particularly the non-Orthodox, gene talk becomes a way to talk about distinctiveness or peoplehood, even the specialness of Jews and Jewish history, without the hubris of biblical chosenness. They can discuss "Jewish genes" and their relationship to "the Jewish experience" without relying on what some see as an arrogant religious claim.

For Messianic GBs, by contrast, reaffirming chosenness is central. It is precisely the theology of inherited Jewish difference that draws them to the movement since it makes Jews a definable group that corresponds to particular biblical histories and End Times prophesies. Nearly all GBs are also consciously seeking a religious alternative to the churches in which they were raised or a complement to the churches they may continue to attend. Gene talk becomes part of this purposeful spiritual trajectory, bolstering how they read the Bible and incorporate rituals into their faith lives. Importantly, GBs are evangelicals who expect a personal experience of spiritual discovery (being "born again"). Thus when they gene talk, they are also wrestling with how to frame the role of the (Jewish) community vis-à-vis the importance of the (born again) individual.

\section{Defining Race in Jewish Gene Talk}

Geneticists remind us that DNA is not race. "Race is a social concept, not a scientific one," geneticist J. Craig Venter explained after a National Institutes of Health project that considered the human genome and its implications for race. ${ }^{53}$ Race is not strictly biological; it is 
socially constructed. Some of the challenge of understanding this, however, comes from the fact that the social construct of race makes reference to the biological and the bodily. Even our colloquial names for racial categories rely on bodies: when we refer to "blacks" or "whites," we make reference to a purported skin color. Race, then, is not properly a biological category, but it operates under such a guise in our social world.

Gene talk-as well as other conversations about Jewish noses, sense of humor, or intelligence, to name a few-suggests that Jews have heritable characteristics that are sometimes physical and sometimes dispositional, and that they have tendencies that are particularly Jewish and not shared with other groups. When black or Asian Jews walk into American synagogues, for instance, they are often met with questions about their Jewishness. ${ }^{54}$ Similarly, the racialist structure of Jewish gene talk can conceal Sephardim and Mizrahim-Jewish populations with ancestry from the Middle East, North Africa, and the Mediterranean-from discussions about who is a Jew. Perhaps unsurprisingly, our research suggests that Sephardim whose families immigrated to North America in the last two generations are less likely to engage in gene talk. Most of the genes that people call "Jewish genes" are actually markers that occur in higher frequencies in Ashkenazi populations, not Sephardi ones. The so-called breast cancer genes BRCA1 and BRCA2, Tay Sachs, Gauchers, and more than a dozen others are often referred to as "Jewish Genetic Diseases," even though they only affect Ashkenazim and not Sephardim at higher rates than the general population. Ashkenazim make up the majority of North American Jews, and this kind of gene talk reinforces the idea that they are the real Jews, or the center of Jewish life. This racialist undercurrent of gene talk also marginalizes adoptees and converts, who find themselves written out of "the Jewish people" when Jewishness is so closely entangled with genetics.

The popularity of stories about the Lemba and the $\mathrm{CMH}$ or Latino anusim offers another compelling example. These people do not "look Jewish," most Americans think. If race is visible on the human body, and if these people do not match the physical heritable characteristics they associate with Jews, they should not be Jewish. But if they have "Jewish genes" and perform rituals that seem Jewish, they present a confusing case. These groups shed light on the ways that religion, race, and ethnicity are often fused in American Jews' imaginations. They assume that Jewish people are ethnically Jewish, have a relationship to Judaism (either they practice it or reject it), and have "racial" similarities based on descent and geographic origin. 
The entanglement of race and religion is complex even for Jews who look white, or "stereotypically Jewish." As Shaul Magid argues in American Post-Judaism, ethnicity and peoplehood have become increasingly messy categories for defining American Jews. ${ }^{55}$ We could add the complications of racial identity to that mix. MyJewishLearning.com reprinted an article about the origin and history of the term "semite," entitled "Who Are the Semites?" One of the article's commenters wrote: "My Jewish ancestors are from Lithuania, Russia and Poland. My sister sent in my Dad's DNA. Came back showing Sephardic connections... how do I find out my race?"56 These comments suggest that even Jews who look white assume that DNA holds clues to their identity and social place, and one of these key social places is race.

If Jewish gene talk exists at the boundaries of race and religion, does it confound both categories, like Henry Goldschmidt argues of Chabad's idea of the "godly soul"? Goldschmidt contends that Chabad's theology about Jewish bodies calls into question the very categories of race and religion, as well as the boundaries between the two. ${ }^{57}$ Gene talk, on the other hand, leaves the categories of religion and race largely intact. Though it also draws on theological, scriptural, and bodily meanings, Jewish gene talk is an example of how discourses about race operate, rather than an instance that challenges conceptions of race as a socially constructed classification of people and their bodies. Unlike Goldschmidt's example, then, Jewish gene talk often relies on-and even reinscribes-dominant social ideas of race, including its relationship to physiognomy and biology. The genetic discourse about the Lemba and anusim, for instance, substitutes genetics for skin color as the determining factor of racial Jewishness, but it does not problematize the existence of the categories of race and religion.

\section{Tracing Lineage and Seeing Race in Messianic Congregations}

Messianic Jews are highly conscious of links between DNA and theology. Indeed, gene talk appeals precisely because of how it fits with a premilliennial theology that sees Jews as a chosen people set apart from the rest of the humanity. GBs often enumerate essentialized traits that they view as inherited through the Jewish bloodline, ranging from the physiognomic (big noses) to the societal (community-oriented, book-smart). ${ }^{58}$ At Beit HaMoshiach, Pastor David's congregation in the northeast, many GBs also associate Jews with a quasi-inherent ability to suffer that they sometimes refer to as the "persecution gene." The idea likely derives from the covenantal theology David preaches: God chose 
Jews to suffer so that the rest of the world would learn from their mistakes.

Yet GBs are circumspect about calling Jews a "race." One reason is the common North American understanding of race as a set of innate physical characteristics defined primarily by skin color. ${ }^{59}$ Like North American Jews in general, more GBs are now familiar with Sephardim and know that they are not easily defined as "white." They are also convinced by the rediscovery of Jews "hidden" since the Spanish Inquisition or "lost" since the dispersal of the ten Israelite tribes. Their rediscovery is seen as a key sign that God is gathering his people for the End Times. ${ }^{60}$ That there is shared DNA among differently "raced" Jews is thus, for GBs, both a sociological fact and of great theological import. On a personal level, too, the fixity of (visible, phenotypic) race belies how GBs understand their own spiritual biographies, where they discovered a "heart" for Jewishness - their own and Jesus' -after being born again. This idea draws on longstanding Anglo-Protestant notions about the interaction between body and soul, where the flesh may serve as a conduit for grace and attest to inner spiritual attributes. ${ }^{61}$ For many GBs it is thus logical that they might find out that their bodies-defined by DNA-do actually reflect how their souls have been transformed by the discovery of a "Jewish heart."

In short, a deep paradox between (racial) fixity and (spiritual) discovery pervades the gentile experience of Messianic Judaism. These questions have become more urgent as growing numbers of GBs diversify the movement. Congregations in Canada and the United States include North Americans of African, European, and Hispanic origin and draw immigrants from across the globe, especially from the Caribbean, Africa, and Latin America. ${ }^{62}$ In the five congregations under study here, between one-quarter and two-thirds of participants are people of color. Melech Israel, for example, is a congregation in a large southern U.S. city that draws about 150 people to its weekly worship services, with another 300 or so tuning in online. Its leader, Rabbi Mike, grew up in an Ashkenazi home and was born again as an adult. Mike estimates that 35-40 percent of his congregation is "ethnically" Jewish; it is also about 60 percent black (35 percent Islanders, the rest African or African American), 10 percent Hispanic, and 30 percent white. While most of the congregation's Jews identify as white, 10 percent or so are African and Hispanic. ${ }^{63}$

Melech Israel's congregants engage gene talk in two main ways, both of which are also representative of the other groups in this study. The first is to be attentive to clues within one's own make-up or actions that might be outward signs of a particular DNA. Here GBs' understanding of scientific objectivity ${ }^{64}$ overlaps with the pietistic 
heritage of evangelical Christianity, wherein believers are expected to create and sustain emotionally immersive relationships with Jesus, God, and - in the case of premillennialists - with God's people, the Jews. The intensity of these connections leads GBs to deduce that perhaps they have a "calling" in their blood, an idea that Bennett Greenspan, for example, subtly encourages. ${ }^{65}$ Karyn, an African American in her late fifties, is typical. "I've always questioned [if I might be Jewish]," she says, "because of the love and the commitment being so deep, and even my family...they used to tell me I was strange. So I know that I'm not 'the typical person' culturally speaking." Later, she notes that Jewish-style worship "felt like coming home. This is the other half that has been missing. I'm just coming in touch with my Jewish roots." While "roots" could be taken metaphorically, Karyn implies that something within her called her home. Anthropologist Circe Sturm notes a similar idea among (white) Americans who come to self-identify as Cherokee Indian. These "racial shifters," as Sturm calls them, view blood as containing "genetic memory," an animating life force that connects people today with (even unknown) ancestors. Thus they "literally" carry the DNA of their ancestors within them. ${ }^{66}$

Second, GBs combine this kind of gene talk with a strong emphasis on tracing Jewish lineage. Evangelical Christians try to read most major events in their lives within a biblical framework and gene talk appeals, at one level, because it seems to mirror biblical typologies, especially the genealogical lists in Genesis and Leviticus. From a historical perspective, the exegetical tradition upon which they draw is also based on nineteenth-century attempts to classify biologized races according to the book of Genesis. Scholars of religion have examined how, for example, Native Americans were viewed as descended of the Ten Lost Tribes or African Americans of Noah's son Ham. ${ }^{67}$

Although Noachite lineages undergirded this early "race science," ${ }^{68}$ GBs today rarely refer to the period before Abraham, likely because he marks the beginning of God's covenant with the Israelites and its attendant promises. Gene talk does, however, often rest on Abraham, in effect widening the Jewish bloodline sufficiently as to encompass nearly everyone. "God said to Abraham that he'd have many descendants," notes Donald, a fifty-year-old white congregant at Melech Israel: "I was not brought up Jewish. I don't know that I have any Jewish heritage at all. But I may have Jewish ancestry but that far back, I won't know it. And so I don't say that I'm not, but I don't say that I am." To speak in such generalities is common among Messianics and is never sufficient to make a real claim to Jewish blood. To do so, GBs must refer to more specific socio-historical events, tracing their family to lost or hidden Jews, as Polly does above. As per Gil Anidjar's 
recent discussion of changing notions of blood, one might say that Messianic gene talk engages "blood" in the biblical sense of family memory, naming practices, and genealogical lists and also mobilizes newer ideas about inherited, transmissible characteristics. ${ }^{69}$

This gene talk is more or less believable to other congregants based on one's (visible) race and the authenticating lineages associated with it. White GBs of German and Eastern European ancestry, like Polly, usually make the strongest claims, which rest on the perception that, with so many Jews in these regions, there was certainly mixing and hidden identity. GBs of Western European descent have more difficulty discovering convincing lineages and tend not to try, although they may exert a kind of privilege whereby they can rise within denominational ranks as confirmed allies of the Jews. ${ }^{70}$ They also sometimes "pass" as Jews among non-Messianic colleagues and acquaintances, a mistake they take as a compliment and may even encourage.

North American-born blacks have no such privilege. Probably as a result, in the congregations under study they were both the most likely to speculate about being Jewish and the most likely to have these claims rejected or ignored by other congregants. They were also the most adamant that Jewishness is not a "race," meaning a particular phenotype. There are good reasons for their insistence. Despite increased awareness of the Sephardim and "lost tribes," Messianic Jews (and especially the leadership) view normative Judaism as not black. Eva, a fifty-one-year-old congregant at Melech Israel, shows how African Americans often approach the issue when she says,

I wondered sometimes [if I was Jewish] because I don't know all of my family background. But sometimes if I would look at my father and look at his nose-he's like Jewish! So I've wondered, but I never tried to check [with DNA testing]. I know that Jews, they're in places like Africa, but when I was growing up... a Jew ... was just another white person!.... [But at Melech Israel,] like the [Hispanic] man [leading the Torah class]: he's Jewish. He's Sephardic. Or John from the Caribbean. John is Jewish, and you look at him and you just think, "Oh, he's another black man." ... So right now, we don't know who's the gentile and who's the Jew! Because many people of color are Jews. Yes, through the line of Ephraim and Manasseh. And then, also come on: men are men. So you could come from any of the lines.

Eva takes a three-pronged approach. First, she emphasizes the importance of Sephardim, the Jews "of color." Second, she highlights 
the older idea that Africans are descended of a particular biblical lineage, in this case Ephraim and Manasseh, two of the "lost" tribes of Israel. ${ }^{71}$ This idea, which is common among black GBs, relies on nineteenth-century Anglo-Protestant race science but reinterprets it. Rather than being one branch of humanity, descended of Noah's cursed son Ham, Africans become part of the covenanted Jewish people, descended of two of Joseph's sons (thus Jacob/Israel's grandsons). Third, Eva's description ends by drawing on the now popular understanding of African Americans' genetic pool as comprising every possible permutation. "Men are men," she says, meaning that Jewish men undoubtedly impregnated black slaves, passing "genetic" Jewishness down. While this explanation may jibe with television shows like PBS's Finding Your Roots and TLC's Who Do You Think You Are, it is utterly rejected by the Messianic leadership since it impugns the moral character of Jewish men and undoes the myth of pure endogamy also promoted by mainstream Jews, such as Chabad.

Unlike African Americans, immigrants from Africa and the Caribbean may exert strong claims if they follow recognized patterns of the "hidden" Jew. An African who describes descent from the Falasha or Lemba is nearly always accepted as Jewish, as is someone who describes a believable (and less morally problematic) historical trend. "We actually have a cute story [about] this," Rabbi Mike recounts. "We had a rabbi come in and he said, 'I am so glad that it's multiculturalAfrican-American,' and he pointed to one gentleman in particular. And we all started laughing because he's actually Jewish. And not only was he Jewish, he has proof he's Jewish! His family ended up in the [Caribbean] islands, but his family - they traced it back to China and through trade routes to Jerusalem." When Mike emphasizes proof, he means a family lineage that follows accepted patterns within Messianic (and mainstream) Judaism - the "wandering" Jewish trader who originated in Jerusalem.

Yet it is also African or Caribbean immigrants who often make the most problematic claims to Jewishness that must be "cut out" to paraphrase Rabbi Mike above. ${ }^{72}$ Pastor Solomon, for example, is a Nigerian immigrant who leads a small Pentecostal Messianic Jewish group in a northeastern city. He describes how in "some areas in Nigeria they practice exactly like the Israelites, and they are descended of the Egyptian Jews who migrated. Our background was from this on my mother's side." He knows this ancient lineage, he says, because God spoke to him directly. He further intuited it from the religious practices in his Nigerian independent church. Later, at a North American Messianic service, he "just felt something, like a very good connection. And I felt that God had sent me there." While Solomon 
does not insist on identifying as a Jew, his claim is one reason he broke with the other local congregations and created his own, which remains unaffiliated with a Messianic denomination. Indeed, denominational leaders would balk at having a congregation led by a dark-skinned Nigerian who claims Jewish descent through a tribe of migrating Egyptians. It is idiosyncratic and fails to correspond to any recognized typologies of the hidden Jew.

Part of the issue is that Messianic leaders are attuned to how such claims may be perceived by mainstream Jews, from whom they seek authentication. Many leaders are concerned about congregations filled with people (often, African or African American people) who immediately look like gentiles to "ethnic" Jews, including potential converts. For Rabbi Silvio and Pastor Eric, each serving a congregation in the southwest, it requires a delicate balance. Silvio notes that "[Messianic] Jews are afraid of getting outnumbered, and something that's Jewish becoming not Jewish. The reality is that if I have a whole leadership team that doesn't have Jewish representation, or adequate Jewish representation, then I will lose credibility in the eyes of the unbelieving Jewish world." Pastor Eric concurs. Jews and gentiles are equal in his congregation, "but I admit if you had two trulyqualified individuals honestly you'd go for the ethnic Jew because of their visibility within the group. And as a Jew who had come to faith in Yeshua, it would be a good connecting point [for unbelieving Jews]." ${ }^{73}$

For this reason, the most successful racial shifters are Hispanics and others who can plausibly claim an identity as anusim, a category increasingly recognized by mainstream Jews as well. Not surprisingly, southwestern Messianic congregations have an especially high (and growing) number of people who claim such roots, driven in part by media coverage of DNA studies that seem to offer scientific proof of anusim. Rabbi Silvio estimates that, when he arrived at Beth Yeshua four years ago, only 10 percent of the congregants were Jews. Today that number has risen to 25 percent, mainly because of newly discovered anusim - including Silvio himself. After discovering his roots during his seminary training as a Pentecostal pastor, he married the daughter of a well-known leader in Jewish evangelism and signed up for Messianic ministry. People like Silvio are accepted into congregational leadership as Jews and even celebrated by the largely Ashkenazi opinion-makers at the denominational level (see Table A). In short, it is vitally important to leaders (and many congregants) that all Messianics, but especially public figures such as rabbis, performers, or televangelists, claim Jewishness in ways that converge with "proven" genetic lineages that are also accepted by mainstream Jews. 
TABLE A. Acceptance of congregational leaders by Messianic denominational leadership

By looking at the levels of acceptance of the pastors/rabbis in this study, one sees the authority that certain ancestry narratives exert within Messianic Judaism.

\begin{tabular}{|c|c|c|c|}
\hline Name & Location & Background & $\begin{array}{l}\text { Accepted } \rightarrow \text { Not } \\
\text { Accepted }\end{array}$ \\
\hline Rabbi Mike & South & $\begin{array}{l}\text { Recognized } \\
\text { Ashkenazi home. } \\
\text { Came to faith in } \\
\text { Yeshua as an adult. }\end{array}$ & Highly accepted \\
\hline Pastor David & Northeast & $\begin{array}{l}\text { Recognized Sephardi } \\
\text { home. Came to faith } \\
\text { in Yeshua as an adult. }\end{array}$ & Highly accepted \\
\hline Rabbi Silvio & Southwest & $\begin{array}{l}\text { Hispano-Italian. } \\
\text { Discovered anusim } \\
\text { roots as an adult. }\end{array}$ & Accepted \\
\hline Pastor Eric & Southwest & $\begin{array}{l}\text { Anglo/European. } \\
\text { Wife from celebrated } \\
\text { Messianic Jewish } \\
\text { family }\end{array}$ & $\begin{array}{l}\text { Accepted, but } \\
\text { some questions } \\
\text { about legitimacy } \\
\text { of his leadership } \\
\text { as a gentile. }\end{array}$ \\
\hline Pastor Solomon & Northeast & $\begin{array}{l}\text { Nigerian. Claims } \\
\text { descent from } \\
\text { Egyptian Jews } \\
\text { through divine } \\
\text { revelation }\end{array}$ & $\begin{array}{l}\text { Not accepted. } \\
\text { Disaffiliated from } \\
\text { recognized } \\
\text { Messianic bodies }\end{array}$ \\
\hline
\end{tabular}

\section{Conclusion: Wherefore Gene Talk?}

The particulars of the scientific data rarely matter in gene talk. Instead, we might view gene talk as a religious or religiously inflected practice. It takes place over months and years, cementing community members in a shared discursive tradition that reflects and contributes to the hermeneutics and ontologies that matter to them. For Jews, it mobilizes scientific authority in support of pre-existing conceptions of a natural connection between all Jewish people. ${ }^{74}$ Many Orthodox Jews see genetics as evidence of both the scientific reality of biblical history and a moralized endogamous Jewish past. Though nonreligious Jews rarely cite religious texts, for them gene talk is nevertheless a religiously inflected practice, which builds upon, and reframes, biblical ideas of peoplehood and chosenness. Among GBs, gene talk 
strengthens their conviction not that they are Jewish (necessarily) but that lineage matters: it matters theologically that Jesus was a "genetic" Jew and that today's Jews are "genetic" descendants of Israelites. It also offers a way to engage with mainstream Jewish culture. Gene talk that follows recognized patterns among Jews - relation to Eastern European ancestors, for example, or to the anusim - is more accepted and valued. Messianics who gene talk, whether or not they test their DNA, find a way to participate in the Jewish community by contributing to its authenticating discourse.

In fact, for GBs, actually undertaking genetic testing entails significant risk, not because it could reveal gentile DNA (for there are many ways to construe the data), but in existential and theological terms. According to evangelicals, Judaism as a religion is fundamentally incorrect because it ignores the radical nature of Jesus' claim that through his Messiahship there is no difference between "Jew and Greek." Gentiles are grafted into the Jewish people, uniting the regenerate world of believers in Jesus. If one digs too hard for Jewish roots - moving gene talk into action - it may seem to negate this central gospel promise of new life and togetherness in Christ. On a more personal level, it may imply that being born again is not actually enough: something else is needed to cement one's intimacy with Jesus and with God's people. ${ }^{75}$ In short, premillennialist theology propels GBs toward claiming a Jewish identity and also problematizes it, for to focus inordinately on Jewishness as inalienable and theologically significant has the potential to undermine the gospel promises that are central to evangelicalism.

Gene talk also helps us conceptualize contemporary American notions of race differently, in this case on theological models. While "seeing" race as color and physiognomy is not absent in Judaism or Messianic Judaism, it is crucial to underline how race operates in multiple, shifting ways. This is especially apparent among Messianics, where GBs reject the word "race" precisely because it seems to signal phenotype; for them, inherited qualities are best understood in biblically resonant ways like "lineage." GBs thus consciously work against North American conceptions of race when they insist that "race shifting," as Sturm calls it, is a divine calling apparent in one's actions, rather than one's skin. Jewish blood is instantiated when a gentile feels called "home" to a Messianic congregation, like Karyn, or when she is overcome by emotion during Hebrew prayers. This "call" fits within evangelical theology, where the exterior may remain unchanged while the interior soul undergoes a major spiritual renewal.

While we focus on Judaism and Jewish-related movementswhere genetic testing and gene talk are especially prevalent-we end with a call for comparative research, especially among groups with 
deeply entangled concepts of religion and race or ethnicity. To date, notable studies have examined genetics in light of Latter-day Saint theology, for example, leading to significant debate within that church. ${ }^{76}$ Anthropologist Fenella Cannell has produced some of the most sophisticated work in this regard, noting how U.S. Mormons undergo a patriarchal blessing in which each one is ascribed an Israelite tribal lineage (or not) that may disrupt his or her socially defined "race"; for example, it may be revealed that someone who self-identifies as white is "of Manasseh" (associated with Native Americans) or "of Abraham" (not in the line of Jacob/Israel and thus associated with African Americans). In Cannell's words, LDS "patriarchs may 'see' hidden elements of the history of 'race' by means of prophetic inspiration." ${ }^{\prime 77}$ In keeping with our findings among Jews and Messianic Jews, there is fluidity and an element of discovery or surprise associated with what is viewed as heritable characteristics. Other fruitful comparisons might include work among indigenous North Americans, African Americans, or French-descent Quebecois, to name just a few possibilities. The noted popularity of genealogy and genetic testing in North America (and across Western Europe) also offers numerous possibilities for thinking more expansively about how mainline Protestants, for example, or the "spiritual but not religious" and "nones" may engage such practices and thus religion in unexpected ways.

In sum, our comparative case study of Jews and Messianic Jews demonstrates how North Americans may retain and produce theological readings of DNA testing, despite the seemingly secular nature of science. As a result, our work reinforces how North American culture and religion are interpenetrative and work together to create authoritative narratives of identity. More particularly, attending to gene talk in these and other social locations is one step toward analyzing the dense intersections between religion, bodies, and popular understandings of science, creating new avenues for understanding American religion in the process.

\section{Notes}

1. "Jewish Voice with Jonathan Bernis: Your Jewish Identity" https://www.youtube.com/watch?v=O42hXF6RB3U (Accessed March $22,2015)$.

2. Two denominational associations (UMJC, MJAA) formed in the 1970s, with which many congregations affiliate. Although Messianic Judaism is clearly growing, estimates of adherents vary widely from thirty thousand to three million. The number of GBs is also persistently debated 
and downplayed. Recently, historian Yaacov Ariel estimated the number is 25-50 percent, relying on a two-decades-old source by Messianic rabbi Michael Schiffman, Return of the Remnant: The Rebirth of Messianic Judaism (Baltimore: Lederer Publications, 1992). Nearly all scholars cite 50 percent in part because they echo Messianic Jewish leaders (for whom it is the acceptable limit in a "Jewish" movement) and because ethnographers, especially, have studied flagship congregations with high Jewish involvement. A broader demographic survey is needed; however, based on this study of five sites, it seems clear that in most cases GBs account for at least 70-80 percent of attendees. Ariel, An Unusual Relationship: Evangelical Christians and Jews (New York: New York University Press, 2013), 233; Hillary Kaell, "Born-again Seeking: Explaining the Gentile Majority in Messianic Judaism," Religion 45 (2015): 43 n. 3.

3. Jonathan Tobin, "Jews for Jesus and Santorum," Commentary, March 22, 2012, http://www.commentarymagazine.com/2012/03/22/ jews-for-jesus-and-santorum/. Accessed October 5, 2014.

4. Nathan Guttman, "Jewish Lawyers Take Forefront in Representing Gitmo Detainees," Jewish Daily Forward, October 2, 2009. "The Genesis of Our Future," http://urj.org/about/union/leadership/rabbijacobs/ ?syspage=article\&item_id=109240.

5. Elizabeth Hirschman and Donald Panther-Yates, "Peering Inward for Ethnic Identification: Consumer Interpretation of DNA Test Results," Identity: An International Journal of Theory and Research 8 (2008): 48.

6. Data on Messianics is based on twelve months (2012-2013) of participant observation by the authors and two research assistants at five sites in three mid-sized North American cities. Besides attendance at worship, Bible studies, and other activities, we conducted fifty-six-long-form conversational interviews with GBs and congregational leaders. Research also included periodical reviews of conservative Christian media and the full run of the Messianic magazine Kesher, as well as six interviews with Messianic denominational leaders in 2010. The research on Jews consisted of participant observation in three online Jewish genealogical groups (2013-2014) and data analysis from twenty-nine Jewish websites, including those highlighted in Ari Y Kelman, "The Reality of the Virtual: Looking for American Jewish Leadership Online" (AVI CHAI, Foundation, 2010), http: / / www.bjpa.org/Publications/details.cfm?PublicationID=12881. Historical and archival work complement the contemporary studies.

7. Kim Tallbear, Native American DNA (Minneapolis: University of Minnesota Press, 2013), 4. The first commercial DNA testing service 
began in 1998. For a list of some media related to genetic testing, see Hirschman and Panther-Yates, "Peering Inward for Ethnic Identification," 49.

8. Susan Martha Kahn, "The Multiple Meanings of Jewish Genes," Culture, Medicine and Psychiatry 29 (2005): 179-92. Susan Martha Kahn, "Are Genes Jewish?" in Boundaries of Jewish Identity, ed. Susan Glenn and Naomi Sokolov (Seattle: University of Washington Press, 2010), 12-26. Nadia Abu El-Haj, The Genealogical Science (Chicago: University of Chicago Press, 2012).

9. Kahn cited above; Miryam Wahrman, "Fruit of the Womb: Artificial Reproductive Technologies and Jewish Law," Journal of Gender, Race and Justice 109 (2005-2006): 109-37.

10. On debates about gentile conversions see volume 6 of Kesher: A Journal of Messianic Judaism (Winter 1998).

11. Sarah Imhoff, "Traces of Race," in Who Is a Jeww? ed. Leonard Greenspoon (Purdue University Press, 2013), 1-20.

12. Kwame Anthony Appiah, My Father's House: Africa in the Philosophy of Culture (Oxford: Oxford University Press, 1992), 13.

13. Matthew Frye Jacobson, Roots Too: White Ethnic Revival in Post-Civil Rights America (Cambridge: Harvard University Press, 2008), 6. Sociological texts promoting this idea include Mary C. Waters, Ethnic Options: Choosing Identities in America (Berkeley: University of California Press, 1990) and Joan Nagel, American Indian Ethnic Renewal: Red Power and the Resurgence of Identity and Culture (1996). On Jews in this ethnic revival, see Jacobson, Roots Too, 18-70.

14. Waters's Ethnic Options directly influenced early studies of Messianic Judaism, including Shoshanah Feher, Passing Over Easter: Constructing the Boundaries of Messianic Judaism (Lanham, Md.: AltaMira Press, 1998), Carol Harris-Shapiro, Messianic Judaism: A Rabbi's Journey through Religious Change in America (Boston: Beacon Press, 1999), and relatedly, Janet Jacobs, Hidden Heritage: The Legacy of the Crypto Jews (Berkeley: University of California Press, 2002).

15. Feher, Passing Over Easter, 48.

16. An exception is Fenella Cannell who parses the intersection of race/ethnicity, religion, genealogy, and to some degree genetic testing in her studies of Latter-day Saints. Cannell, "The Blood of Abraham: Mormon 
Redemptive Physicality and American Idioms of Kinship," Journal of the Royal Anthropological Institute 19 (2013): S77-94. Sylvester Johnson is another exception, although his interest lies not in gene talk but in the relationship between black ethnic talk and religion. Johnson, "The Rise of the Black Ethnics: The Ethnic Turn in African American Religions, 1916-1945," Religion and American Culture 20 (2010): 125-63.

17. Gil Anidjar, Blood: A Critique of Christianity (New York: Columbia University Press, 2016), 49, 83.

18. Colin Kidd, The Forging of Races: Race and Scripture in the Protestant Atlantic World, 1600-2000 (Cambridge: Cambridge University Press, 2006), 2. Audrey Smedley and Brian Smedley, Race in North America: Origin and Evolution of a Worldview (Boulder: Westview Press, 1993), 154-55.

19. Circe Sturm, Becoming Indian: The Struggle over Cherokee Identity in the Twenty-first Century (Santa Fe: School for Advanced Research Press, 2010).

20. Beth El Synagogue Genealogy Club, "DNA and Jewish Genealogy," http://www.jewishpmb.org/jewish-federation-of-princetonmercer-bucks-calendar/633. Accessed March 22, 2015.

21. "iGenea," sidebar ad at google.com. Accessed September 4, 2012).

22. "Family Tree of the Jewish People," http://www.jewishgen. org/gedcom/. Accessed March 22, 2015.

23. The $\mathrm{CMH}$ is present in other populations, in particular among Arabs and Kurds. Karl Skorecki et al., "Y Chromosomes of Jewish Priests," Nature 385 (1997); Michael A. Hammer et al., "Extended Y Chromosome Haplotypes Resolve Multiple and Unique Lineages of Jewish Priesthood," Human Genetics 126 (2009): 707-17.

24. "Is Aronson a Cohen or a Levi?" http://boards.ancestry. com/thread.aspx?o=10\&m $=15.19 .21 .22 \& \mathrm{p}=$ surnames.aronson. Accessed March 22, 2015.

25. Yaakov Kleiman, "The Cohanim - The DNA Connection," http:/ / www.aish.com/ci/sam/48936742.html. Accessed March 22, 2015.

26. L. Rozovsky, "Raise Your Hand if You're a Kohen," 2013, http:/ / www.chabad.org/library/article_cdo/aid/762109/jewish/RaiseYour-Hand-If-Youre-A-Kohen.htm. Accessed January 11, 2015. 
27. D. Kelly, "Clearing the Fog over Latino Links to Judaism in New Mexico," Los Angeles Times. December 5, 2004.

28. Tudor Parfitt and Yulia Egorova, Genetics, Mass Media, and Identity: A Case Study on the Genetic Research of the Lemba and the Bene Israel (New York: Routledge, 2006). M. Thomas et al., "Y Chromosomes Traveling South: The Cohen Modal Haplotype and the Origins of the Lembathe "Black Jews of Southern Africa," American Journal of Human Genetics 66 (February 2000): 674-86.

29. "Jewish Genealogy by Genetics," http://www.jewishgen. org/DNA/genbygen.html. Accessed March 23, 2015.

30. Henry Marcus post on "Tracing the Tribe - Jewish Genealogy on Facebook." Accessed January 13, 2015.

31. Comments to Deborah Jiang-Stein, "For Crying Out Loud, It's a Culture, Not a Race!" http:/ / www.myjewishlearning.com/blog/ jewish-and/2014/04/. Accessed March 23, 2015.

32. "75 Percent of Today's Jews Have Middle Eastern Origins, Says DNA Pioneer," November 13, 2014, http://www.worldjewishcongress.org/en/news/15353/75_percent_of_today_s_jews_have_middle_ eastern_origins_says_dna_pioneer. Accessed November 15, 2014.

33. Judy Maltz, "DNA Tester: 75 Percent of Jews Trace Ancestry to Middle East," Haaretz, November 13, 2014, 1, 3.

34. David Laskin, The Family (New York: Viking: 2013), 9.

35. Elisha Greenbaum, "The Cohen Gene” http://www.chabad. org/parshah/article_cdo/aid/652568/jewish/The-Kohen-Gene.htm. Accessed September 1, 2014.

36. Ibid.

37. Alex Joffee, "Jewish DNA Speaks" http://www.myjewish learning.com/beliefs/Theology/Who_is_a_Jew/Types_of_Jews/jewishdna.shtml. Accessed October 5, 2014.

38. Comments to David Koffmann, "Native Americans and Jews: The Lost Tribes Episode," http://www.myjewishlearning.com/history/ Modern_History/1700-1914/America_at_the_Turn_of_the_Century / Regional_Judaism/Peddlers_and_Frontier_Judaism/Native_Americans_ and_Jews.shtml. Accessed October, 52014. 
39. Jon Entine, "Israeli Researcher Challenges Jewish DNA Links to Israel, Calls Those Who Disagree 'Nazi Sympathizers,'" Forbes.com, May 16, 2013, http://www.forbes.com/sites/jonentine/2013/05/16/israeliresearcher-challenges-jewish-dna-links-to-israel-calls-those-who-disagreenazi-sympathizers/. Accessed September 1, 2014.

40. Harris-Shapiro, Messianic Judaism, 73.

\section{Feher, Passing Over Easter, 48.}

42. About 85 percent of U.S. Messianic Jews are charismatic, as are 65 percent of congregations, according to Peter Hocken, Challenges of the Pentecostal, Charismatic, and Messianic Jewish Movements: The Tensions of the Spirit (Abingdon: Ashgate, 2009), 97. Four out of five leaders in this multisite study received ordination from Pentecostal seminaries. "Charismatic" means adherence to Pentecostal beliefs, regardless of denominational affiliation.

43. Cannell, "The Blood of Abraham," S91.

44. Jewish organizations that propagate these discoveries include Be'chol Lashon (San Francisco), Kulanu (New York), Amishav (Jerusalem), and Shavei Israel (Jerusalem). Each organization has clear ideological/ theological reasons for finding "lost tribes"- ranging from wanting to grow Judaism in the wake of the Holocaust to a Zionist apocalypticism similar to premillennialist Christian theology.

45. David A. Rausch, "The Emergence of Messianic Judaism in Recent American History," Christian Scholar's Review (1983): 44-45; Robert I. Winer, The Calling: The History of the Messianic Jewish Alliance of America, 1915-1990 (Wynnewood, Pa.: Messianic Jewish Alliance of America, 1990), 9, 11; Yaacov Ariel, Evangelizing the Chosen People: Missions to the Jews in America, 1880-2000 (Chapel Hill: University of North Carolina Press, 2000), 224-25, 229; Ariel, An Unusual Relationship, 218-21.

46. Conversion has long been contentious in Messianic Judaism; as early as 1983, the UMJC released a paper on the topic. John Fisher and Chaim Urbach, "Messianic Conversion: Is it Viable?" Kesher 6 (Winter 1998): 30-49. This is another difference with the LDS, mentioned above: although less popular an idea today, Joseph Smith and Brigham Young believed that "Gentile" converts' blood would be physically changed during Mormon baptism so that after the ritual they too would have the blood of Abraham. Monte S. Nyman, R. Wayne Shute, and Randy L. Bott, Ephraim: Chosen of the Lord (Salt Lake City: Millennial Press, 1999), 63. 
47. Kidd, The Forging of Races, 204.

48. British Israelism influenced U.S. Pentecostalism through the theology of Charles Fox Parham (Kidd, The Forging of Races, 209, 214-16) and, more directly, through Herbert Armstrong's Worldwide Church of God in California. While few GBs seem to come directly from this church (which dispersed in the 1990s), it has influenced the diffuse "Hebraic roots" movement. GBs access both Messianic and Hebraic roots websites on "reclaiming Judaic roots," before and during their affiliation with Messianic Judaism.

49. This is not "classic" replacement theology, whereby the church becomes Israel. It is more closely linked to what Messianics often call Twohouse theology (or the "Ephraimite movement"), a kind of replacement in reverse that says the descendants of Ephraim became "the nations" foretold in Genesis 48:19 — that is, the lost tribes of Israel-who will now join the Jews (descendants of Judah) to share in the eschatological promises.

50. See, for example, Ray Gannon, Sam Richardson, and Bruce Stokes, "Gentiles in the Messianic Community," Kesher 6 (Winter 1998): 61-78. Also, Strum, Becoming Indian, 9.

51. This pattern is found among crypto-Jews, too: Jacobs, Hidden Heritage, 96. Kaell,"Born-again Seeking," 17.

52. Cannell, "The Blood of Abraham," S88.

53. Natalie Angier, "Do Races Differ? Not Really, DNA Shows," New York Times, August 22, 2000, F1, F6.

54. Judith Weisenfeld, "On Not Being Jewish ... and Other Lies," Soundings 1 (2003): 3-11; Melanie Kaye-Kantrowicz, The Colors of Jews: Racial Politics and Radical Diasporism (Bloomington: Indiana University Press, 2007), 33-46.

55. Shaul Magid, American Post-Judaism (Bloomington: Indiana University Press, 2013).

56. Comments to Bernard Lewis, "Who Are the Semites?" http:/ / www.myjewishlearning.com/beliefs/Theology/Who_is_a_Jew / Types_of_Jews/Semites.shtml. Accessed October 5, 2014.

57. Henry Goldschmidt, "Religion, Reductionism, and the Godly Soul: Lubavitch Hasidic Jewishness and the Limits of Classificatory Thought," Journal of the American Academy of Religion 77 (2009): 547-72. 
58. Ariel, An Unusual Relationship, 146. Among crypto-Jews: Jacobs, Hidden Heritage, 141, 174 n. 20.

59. George Fredrickson, Racism: A Short History (Princeton, N.J.: Princeton University Press, 2002), 5; Michael Orni and Howard Winant, Racial Formation in the United States: From the 1960s to the 1990s (New York: Routledge, 1994), 55.

60. Kidd, The Forging of Races, 43-45; Zvi Ben-Dor Benite, The Ten Lost Tribes: A World History (Oxford University Press, 2009).

61. R. Marie Griffith, Born Again Bodies: Flesh and Spirit in American Christianity (Berkeley: University of California Press, 2004), 6.

62. Based on averaged estimates by the five rabbis/pastors in this study, 48 percent of their congregants are non-white and 38 perrcent foreign-born. Scholars have noticed this increasing diversity. Shoshanah Feher's study of a California congregation tracks it between 1992 and 2000. Feher, "Challenges to Messianic Judaism," in Voices of Messianic Judaism: Confronting Critical Issues Facing a Modern Movement, ed. by Dan CohnSherbok (Clarkesville, Md.: Messianic Jewish Publishers, 2001), 226.

63. Of forty-nine interviews with congregants, the self-defined racial breakdown is 59 percent white (29), 18.4 percent black (9), 8 percent Hispanic (4), 8 percent Asian (4), 4 percent biracial/black (2), 2 percent Arab (1). Whites are slightly overrepresented in this sample and blacks/Hispanics underrepresented, partly because some congregational leaders discouraged our interviews with non-whites, for reasons noted in this article.

64. GBs use "scientific" as shorthand for something that, no matter how hard one prays or wills it, cannot be changed, such as bloodline (though prayer may lead to discovering a hidden lineage).

65. Rita Rubin, "Tapping into Growing Lure of Hidden Jewish Heritage Online," Jewish Daily Forward, June 18, 2013, http://forward. com/articles/178628/tapping-into-growing-lure-of-hidden-jewish-heritag/ ?p=all; Simon Romero, "Hispanics Uncovering Roots as Inquisition's 'Hidden' Jews," New York Times, October 29, 2005, http://www.nytimes.com/ 2005/10/29/national/29religion.html; Greenspan's tone changes when he is not addressing crypto-Jews and other Jewish roots seekers: see, for example, Ron Nixon, "DNA Tests Find Branches but Few Roots," New York Times, November 25, 2007, http://www.nytimes.com/2007/11/25/business / 25dna.html?pagewanted=all\&_r=0. All sites accessed January 23, 2015.

66. Sturm, Becoming Indian, 41. 
67. Johnson, "Rise of the Black Ethnics;" Henry Goldschmidt, "Introduction: Race, Nation, and Religion," in Race, Nation, and Religion in the Americas, ed. Goldschmidt and Elizabeth McAlister (New York: Oxford University Press, 2004), 3-34.

68. Kidd, The Forging of Races, 20, 35-41.

69. Anidjar, Blood, passim.

70. Scott Moore, "Gentiles and the Spirit of Adoption," Kesher 11 (Summer 2000): 102-16.

71. The reference to these tribes likely comes from British Israelism, which focused on Ephraim in particular, and later Menasseh (Kidd, The Forging of Races, 204, 213). For this reason, the "two-house" movement may be called "Ephraimites" (see note 44). On parallels with Latter-day Saints, Armand L. Mauss, All Abraham's Children: Changing Mormon Conceptions of Race and Lineage (University of Illinois Press, 2003), 161-65.

72. Admittedly immigrants are a small percentage of this sample; however, many did hail from independent churches with Jewish-like rituals and/or replacement theologies. Scholars have also engaged in acrimonious debates about whether the prevalence of such churches among Hispanics is driving the discovery of anusim. See Judith Neulander, "The Crypto-Jewish Canon: Choosing to be 'Chosen' in Millennial Tradition," Jewish Folklore and Ethnology Review 18 (1996); 19-59; Stanley Hordes, "The Sephardic Legacy in New Mexico: A History of the Crypto-Jews," Journal of the West 354 (1996): 88; Seth D. Kunin, "Juggling Identities among the Crypto-Jews of the American Southwest," Religion 31(1) 2001: 45, 58 n. 5.

73. Harris-Shapiro, Messianic Judaism, 73.

74. Yulia Egorova, "The Proof Is in the Genes? Jewish Responses to DNA Research," Culture and Religion 10 (2009): 159-75.

75. See, for comparison, Sturm, Becoming Indian, 61.

76. Mauss, All Abraham's Children; Thomas Murphy, "Simply Implausible: DNA and a Mesoamerican Setting for the Book of Mormon," Dialogue: A Journal of Mormon Thought 36 (2003): 109-31; Simon Southerton, Losing a Lost Tribe: Native Americans, DNA and the Mormon Church (Salt Lake City: Signature Books, 2004).

77. Cannell, "The Blood of Abraham," S87; Mauss, All Abraham's Children, 34-35. Both authors note that these ideas about racialization have 
changed significantly in the last generation and also that they are not crudely racialized; for example, uncommon tribal ascriptions, such as Isaacher or Asher, are expected to emerge in the End Times and are not connected with any known contemporary "race."

ABSTRACT Based on ethnographic and archival research conducted on North American Judaism and Messianic Judaism, this article argues that each group uses DNA in what appear to be sociologically similar ways but that actually differ profoundly at the theological level. Our analysis moves beyond DNA testing per se to focus on what anthropologist Kim Tallbear calls "gene talk," referring to "the idea that essential truths about identity inhere in sequences of DNA." Contrasting Jews and Messianic Jews, we demonstrate clearly what scholars have only begun to recognize: how theological commitments may drive investments in genetic science and interpretations of it. Further, we show how religiously significant identities associated with race, ethnicity, or lineage interact with DNA science, coming to be viewed as inalienable qualities that reside in the self but move beyond phenotype alone. Finally, we argue that gene talk in these contexts is a religiously inflected practice, which serves to binds communities and (implicitly or explicitly) authorize existing theological ideals.

Keywords: race, Judaism, Messianic Judaism, genetics, science, identity 